\title{
Building Brands a Study with Special Reference to Small Car Market in India
}

\author{
Mr. Manjunatha. $\mathrm{V}^{1}$, Dr Amulya $\mathrm{M}^{2}$ \\ ${ }^{1}$ BE, MBA, M.Phil. UGC-NET, Assistant professor Department of Business Management SBRR Mahajana First \\ Grade College Jayalakshmipuram Mysore Karnataka 570012 India, pursuing his PhD programme in the area \\ of Brand Management. \\ ${ }^{2}$ BE MBA PhD Assistant professor DOS in MBA BIMS, Manasagangothri, and University of Mysore Karnataka \\ India designed the title of the research article and its scope. She has supervised the survey and edited the \\ article.
}

\begin{abstract}
The purpose of this research article is to explore and examine the key determinants Brand Building Strategies practiced by the automobile manufacturers in the Indian Small Car Market. Taking the literature support from the past Brand Management researchers the survey is designed to study the Brand building Dimensions such as,Brand Awareness/Brand Knowledge, Brand Image, Brand Identity, Brand Positioning, Brand Trust, Brand Associations, Brand Loyalty, and Perceived quality, across the small car manufacturers in the Indian Automobile market. The survey is limited to five major cities of Karnataka state (Mysore, Bangalore, Mangalore, Davanagere and Gulbarga) focussed on the automobile brands such as Maruti-Suzuki, Tata motors, Mahindra and Mahindra, Hyundai and Toyota. The Sample survey is designed with the help of multi stage sampling method \& the sample size is 1000 small car users across the state.

SPSS is used to develop the associated mean and standard deviation measures to analyse the formations of Strong/Weak brands.

The research article provides substantial evidence to claim that the Indian automobile Market is completely saturated with existence of highly saturated Red Oceans (Where Competition snubs Innovation) and the article may initiate the automobile manufacturers in the Indian small car market to create highly evolved/Innovative Blue oceans.
\end{abstract}

\section{Introduction}

India is not an exception for the changes and product innovations happening across the world. Automobile sector is one of the fastest growing sectors in India. During 1970-80 and late 90's, because of the monopoly of few Indian automobile players such as Hindustan motors(Ambassador), Premier Padmini \& the policy restrictions on foreign players, the Indian middle class \& upper middle class potential aspirants are used to wait for more than a year to realize their dream of owning a car as their symbol of luxury/prestige/Social status and even as an asset.

The past Globalization changes are wide spread today and the impact of which can be witnessed in almost all sectors of social, economical and industrial growth \& development of the country. Indian automobile sector is one of the best examples to quote with respect to the various strategic changes, policy deregulations/relicensing, and attraction of FDI.

As a construct of Brand Building strategies the research attempts to focus the discussion on Eight Brand Equity dimensions from the consumer point of view. The major objectives of the research are to determine the Key determinants of Brand Building Dimensions in the Indian Automobile market focused on the Automobile brands such as Maruti-Suzuki, Tata motors, Mahindra-Mahindra, , Hyundai motors, Toyota motors.

WHEELS the major invention ever happened on the planet, it is very hard to imagine the universe without the existence of wheels in it. Evolution of wheels has made life easier to the mankind in their day to day life. The primitive men used to live in jungles. They used to kill animals for their food and used to carry them for long distances to their caves. One day it is believed that a cave man saw a log of wood rolling down, he got very interested as to how the log of wood was rolling. Another day an animal was kept on the logs of wood and slowly as the log of wood moved the animal was displaced from its position, this excited the cave man too. Very soon the caveman took a log of wood and cut it from one side to form a round object which finally came to be known as a "WHEEL". Later on wheels were used to take killed animals from forest to caveman's home, and slowly bullock carts and horse carts also came into existence.

In the present world, technology is seeing the upward trend at an unprecedented rate. The gadget which is new and latest for today is an antique model of tomorrow, in the same way evolution of wheels has seen various changes, modifications, alterations and up gradation since the time it came into existence. Take a look 
around you will see wheels everywhere, be it as tyre or as any circular object which we come across in our day to day life. Wheel is not only referred to the materialistic things but also to the non-materialistic components, for example we refer to the stages of our life as the "never ending cycle of life"-Life on the wheels of Birth and Death

Automobile Industry in India- The past: Car was mere a dream of many of the Indians. Car sounded as if it is a symbol of great riches and high level dignity, the year 1897 always leaves its mark in the Indian history. 1897 is the year, when the first car ran on Indian roads, before this Indians had no idea of how a car looks like? Indian market before independence was merely looked as a market for imported vehicles, only assembling works were taken up by Indian industries and nothing more, assembling of spare parts formed the order of the day. Indian automobile industry mainly focused on servicing, dealership, financing and maintenance of vehicles but not on manufacturing of the same.

Only a decade after India attained its independence manufacturing works started gradually developing in India. Indian transportation requirements were hugely fulfilled by Indian railway services till 1950's. Straight away after independence Indian automobile industries faced several challenges and road blocks due to the reason that manufacturing capability of the Indian based manufacturing companies were restricted by the "rule of license" but the same rule led to greater success in this field in the coming years.

\section{Artificial Intelligence and Autonomous cars}

\section{Automobile Industry - The Future}

For the years ahead 2020-2030 and after, Computers will become exponentially better in understanding the world and Human needs. It is estimated that in the year 2018 the first self-driving cars will appear on roads for public. By the year 2020-25 the entire automobile Industry in India and the across the globe will starts to be disrupted. No more car buyers and no more sellers will persist after 2030.I or you don't want to own a car any more. Definitely we can call a car with our smart phone, it will show up the location and the drive to Destination, just pay for the driven distance and even we could be productive while driving. The next generation probably may not get a driving license and will never own a car. The IT companies (Tesla, Google, and Apple) are expected to give the revolutionary contributions, the road accidents may reduce to one in every 10 million kilometers with autonomous driving. The traditional car manufacturing companies like Maruti Suzuki, Tata Motors etc will have to face the problems of Bankrupt and reduced sales. It is said among R\&D groups of traditional car manufacturing companies with evolutionary business models the engineers and Technical experts are completely terrified of Tesla and Google's Revolutionary business model of Automobile industry. Insurance companies will have massive trouble, because without accidents the insurance will become 100 times cheaper. Their car insurance business model may disappear. Electric and Solar cars are expected to become mainstream mode of transportation by the end of 2030 and the roads, cities will be of less noisy.

Top 10 export destinations for Indian Automobile Industry (2014-15)

\section{Source: SIAM reports}

\begin{tabular}{|l|l|l|l|}
\hline Rank & Country & Value (US\$) & Share \\
\hline 1 & United States & 1.2 billion & $8.4 \%$ \\
\hline 2 & Mexico & $\$ 1$ billion & $6.9 \%$ \\
\hline 3 & South Africa & $\$ 888.8$ million & $6.1 \%$ \\
\hline 4 & United Kingdom & $\$ 637.4$ million & $4.4 \%$ \\
\hline 5 & Sri Lanka & $\$ 596.9$ million & $4.1 \%$ \\
\hline 6 & Bangladesh & \$592.1 million & $4.1 \%$ \\
\hline 7 & Turkey & \$580.4 million & $4 \%$ \\
\hline 8 & Nigeria & \$546.8 million & $3.8 \%$ \\
\hline 9 & United Arab Emirates & \$433.6 million & $3 \%$ \\
\hline 10 & Colombia & \$428.9 million & $3 \%$ \\
\hline
\end{tabular}

The Market Size of Indian Automobile Industry: The Indian Automobile Industry has produced a total of 19.84 million vehicles for the months January-April-2016, including passenger vehicles, commercial vehicles, three wheelers and two wheelers, as against 19.64 million in April-January 2015.

Domestic sales of Passenger Vehicles grew by 8.13 per cent in April-January 2016 over the same period last year. Within the Passenger Vehicles, Passenger Cars rose by 10.18 per cent, during April-January 2016 over April-January 2015.

The domestic sales of Commercial Vehicles increased by 9.43 per cent in April-January 2016 over the same period last year. Sales of Medium \& Heavy Commercial Vehicles (M\&HCVs) increased at 30.19 per cent. 


\section{GDP Contribution: Indian Automobile Industry}

Indian Automobile industry is the single largest industry being able to contribute as much as 10 per cent of the gross domestic product for a country like India. As of 2013, the Indian automobile industry had contributed to almost 7 per cent of the country's GDP. During the time it provided 22 per cent of India's manufacturing GDP and provided around 18 per cent of excise duties to the state exchequer. The Indian automobile industry has also significantly increased the presence of the nation in international markets with a year-on-year increase in exports of approximately 18 per cent. -Business Standard Feb7 2015

\section{Statement of the Problem}

In the context of contemporary globalized economy, if a car user or a Potential buyer prefers a particular Brand of automobile over and above all the possible Brand Differentiations, then it must be (the buying behavior) because of a kind of unique dimensions of "Managing the Brand", the so called Brand Building Dimensions such as

D Brand Awareness/Brand Knowledge (4 indicators,BK1,...., BK4)

$>$ Brand Image ( 5 indicators , BMG 1,....., BMG 5)

$>$ Brand Identity (4indicators BI 1,...., BI 4)

$>$ Brand Positioning (7 Indicators ,BPS 1,.............., BPS 7)

$>$ Brand Trust ( 5 Indicators BT 1,..........., BT5)

$>$ Brand Associations (10 indicators BAW 1,............BAW 10)

$>$ Brand Loyalty (7 indicators BL 1..........BL 7)

$>$ Perceived quality (PQ1 ........PQ6)

Presently we have 19 Automobile (car) brands operating in Indian Automobile Market. (Maruti Suzuki, Tata Motors, Mahindra and Mahindra, Hyundai, Toyota motors, Chevrolet - General Motors, Honda motors, Fiat, Volks Wagen-VW, Ford, Nissan, Renaults, Volvo,•Porche,Mitsubishi,Audi,Bentley-RollsRoyce,BMW,Benz),out of which five are luxury Brands-Audi, Bentley- Rolls-Royce, BMW and Benz.

The earlier researchers (Keller, Aaker, Kapferer, YooDonthi, Srinvasan) have contributed their maximum towards the development of conceptual knowledge relating to the Brand Management, Brand Equity, Brand Associations, Brand Personality-Brand personifications, Brand Loyalty, Buying Behaviors-Purchase intentions across different products, Market Segments and Socio Demographic Profiles.

The survey of Research literature reveals that there exists minimum of empirical evidences to examine and evaluate Brand Building dimensions with regard to the making of Strong /Weak brands and in particularly for Indian Car (Automobile) market

Therefore the following research question is formulated to guide the research on Building Brands.

RQ1: What are the Key determinants, with regard to the making of a Strong Brand?

Objective of the study

To evaluate the key determinants of Brand Building Dimensions of Select automobile Brands in India.

\section{Sampling Design}

\begin{tabular}{|l|l|l|}
\hline Car Users & Total & \\
\hline Maruti Suzuki & 40 Car users from each city $=40 * 5=200$ & 200 \\
\hline Tata motors & 40 Car users from each city $=40 * 5=200$ & 200 \\
\hline Mahindra \& Mahindra & 40 Car users from each city $=40 * 5=200$ & 200 \\
\hline Hyundai Motors & 40 Car users from each city $=40 * 5=200$ & 200 \\
\hline Toyota Motors & 40 Car users from each city $=40 * 5=200$ & 200 \\
\hline Total Sample size & & 1000 \\
\hline
\end{tabular}

Source: Field survey

The Above table provides the inputs related to the sample design for car users. As the car dealers found to be not supportive in sharing the details of their customers data base I have adopted the method of snow ball sampling as well as Convenient Sampling methods to collect the data through the questionnaire survey. In order to justify the representativeness of the population the geographical area of the population under consideration (Karnataka State) has divided into five divisions ie North, South, East, West, and Central districts. The Major urban cities one each from respective divisions is selected for the purpose of conducting survey both for car users and dealers (Automobile Show room dealers).Further an attempt is made to ensure large sample size by systematically stratifying the major automobile brands (as per their market share and wide presence in the geographical area under consideration).The sample size is set at 1000 by limiting standard error (SE) to $5 \%$ and the acceptable error (E) to $0.3 \%$ in the relation, 
$\mathrm{N}=\{(\mathrm{Z}) \cdot(\mathrm{SE}) \div \mathrm{E}\} *\{(\mathrm{Z}) \cdot(\mathrm{SE}) \div \mathrm{E}\}$

Where $\mathrm{N}=$ Sample size, $\mathrm{Z}=1.96$ two tail critical value (assuming that population characteristics and sample characteristics do not differ significantly). The set sample size is further systematically stratified into 200 each across five selected automobile brands Maruti Suzuki ,Tata motors, Mahindra and Mahindra, Hyundai and Toyota motors. In the next stage of sampling the 200 sample size for each automobile brand is distributed equally (40 each) among the five cities under consideration.

\begin{tabular}{|l|l|l|l|l|l|l|l|l|l|l|l|}
\hline Mean Score and standard deviation for Brand Knowledge among the car users \\
\hline N=200 & Maruti-Suzuki & \multicolumn{2}{|l|}{ Tata Motors } & \multicolumn{2}{l|}{ MM } & \multicolumn{2}{l|}{ Hyundai } \\
\hline 1.4.1Brand Knowledge & Mean & SD & Mean & SD & Mean & SD & Mean & SD & Mean & SD \\
\hline $\begin{array}{l}\text { I can quickly recollect } \\
\text { some of the unique features of the } \\
\text { Brand }\end{array}$ & 3.77 & 1.00 & 3.26 & 1.18 & 3.54 & 1.11 & 3.82 & 0.99 & 3.65 & 1.12 \\
\hline $\begin{array}{l}\text { I can quickly recall the symbol and } \\
\text { logo of the Brand }\end{array}$ & 4.07 & 1.00 & 3.84 & 0.97 & 3.79 & 1.07 & 4.03 & 0.92 & 3.81 & 0.91 \\
\hline $\begin{array}{l}\text { I know that the Brand enhances my } \\
\text { social status and pride }\end{array}$ & 3.72 & 1.1 & 3.33 & 1.1 & 3.87 & 1.02 & 3.77 & 1.00 & 3.81 & 1.00 \\
\hline $\begin{array}{l}\text { The Brand is appealing in its } \\
\text { presentation, style \&functionality }\end{array}$ & 3.92 & 0.9 & 3.42 & 0.99 & 3.83 & 1.10 & 3.88 & 0.89 & 3.77 & 1.10 \\
\hline Aggregate Mean \& SD & $\mathbf{3 . 8 7}$ & 1.0 & 3.46 & 1.06 & 3.757 & 1.07 & $\mathbf{3 . 8 7}$ & 0.95 & 3.76 & 1.03 \\
\hline
\end{tabular}

Source: Field survey

Brand Knowledge/Awareness: Referring to Associative network memory model, Brand Knowledge/Awareness is the relative strength of brand node/s or traces in the memory, which can be measured as the consumer/users ability to identify the brand under different conditions (Keller et.al 2011).As the first step of building brands Brand Knowledge/Awareness provides an insight to analyse consumer perceptions and how these perceptions are stored in their memory in the form of specific brand memory nodes. The dimension of Brand knowledge/Brand awareness creates unique brand differentiations so that the marketing managers can design the marketing plan and to develop new products. Creating Brand Awareness can be done by increasing the familiarity, exposure and focussing more on repeated consumer experiences .The brand awareness/Brand Knowledge influence the consumer purchase motivation, Consumer's purchase ability and in general the purchase/buying behaviour at the marketing/sales/distribution outlets (Keller et.al1996, 2011).

With the intention of quantifying Brand Knowledge among the car users the statements such as,

BK1: I can quickly recollect some of the unique features of the Brand

BK2: I can quickly recall the symbol and logo of the Brand

BK3: I know that the Brand enhances my social status and pride

BK4: The Brand is appealing in its presentation, style \&functionality

are examined on 5 point likert scale (Strongly Disagree to Strongly Agree) to develop the aggregate mean score and measure of standard deviation to identify which of the automobile brands have good brand knowledge/awareness as per the perception of the car users.

The table 1.4.1 indicates that the mean scores and standard Deviations for the five automobile brands such as Maruti Suzuki, Tata motors, Mahindra \& Mahindra Hyundai and Toyota towards measuring Brand Knowledge/Awareness. The car users are of Maruti-Suzuki and Hyundai the opinion that they have good awareness about the brand knowledge (Aggregate Mean score 3.87), followed by Mahindra \& Mahindra, Toyota, and the least score is 3.46 for Tata motors.

\begin{tabular}{|l|l|l|l|l|l|l|l|l|l|l|l|}
\hline $\mathrm{N}=200$ & Maruti-Suzuki & \multicolumn{2}{|c|}{ Tata Motors } & \multicolumn{2}{|c|}{ MM } & \multicolumn{2}{|c|}{ Hyundai } & \multicolumn{2}{|c|}{ Toyota } \\
\hline $\mathbf{1 . 4 . 2}$ Brand Image & Mean & SD & Mean & SD & Mean & SD & Mean & SD & Mean & SD \\
\hline $\begin{array}{l}\text { The Brand has created a distinct } \\
\text { image in my mind }\end{array}$ & 3.55 & 1.11 & 3.2 & 0.98 & 3.30 & 1.14 & 3.52 & 1.03 & 3.36 & 1.17 \\
\hline $\begin{array}{l}\text { The Brand provides me relative } \\
\text { life style }\end{array}$ & 3.71 & 0.93 & 3.48 & 0.89 & 3.62 & 0.99 & 3.61 & 1.02 & 3.66 & 0.98 \\
\hline The Brand is prestigious to me & 3.62 & 1.039 & 3.5 & 0.96 & 3.63 & 1.07 & 3.63 & 0.95 & 3.47 & 1.18 \\
\hline The Brand offers me luxury & 3.65 & 1.069 & 3.08 & 1.05 & 3.61 & 1.09 & 3.70 & 0.98 & 3.73 & 0.98 \\
\hline $\begin{array}{l}\text { The Brand is flashy in its } \\
\text { appearance }\end{array}$ & 3.64 & 1.051 & 3.27 & 0.90 & 3.49 & 1.02 & 3.67 & 0.86 & 3.74 & 0.94 \\
\hline Aggregate Mean \& SD & $\mathbf{3 . 6 3}$ & 1.039 & 3.31 & 0.96 & 3.53 & 1.06 & $\mathbf{3 . 6 3}$ & 0.97 & 3.59 & 1.05 \\
\hline
\end{tabular}

Source: Field survey

Brand Image: Brand Image has been recognized as the most important source of creating strong brands, and it serves as the major determinant to shape/guide the consumers perceptions. Strong Brand Image leads to strong favorable and unique associations to the brand in the memory of its users/customers. Therefore Brand image is 
the reflections of Brand associations stored in the memory/informational nodes (Keller et.al 2011) ant it forms the fundamental base for building strong brands as it forms a rational bridge between Brand Awareness. Brand Knowledge and Brand Associations. Building strong brands (Enhancing the Brand Equity) is sequentially represented in four consecutive steps. (Ref: www.businessdictionary.com)

$>$ Identify the Brand with the right kind of customers and align with their needs, try to associate with the hearts and minds of the customers with specific product class/customer need.

$>$ Establish the totality of brand meaning in the minds of the customers, so that a relevant brand message can be constructed and delivered to the target customers addressing both tangible and intangible associations to stimulate positive customer responses.

$>$ Elicit the proper customer responses and establish strong brand identification with the target group of customers.

$>$ Convert brand response to create an intense, active loyalty relationship between customers and the brand to ensure Brand resonance and ultimately to have the manifestation of the strong brands. (Keller et.al 2011)With the intention of quantifying Brand Knowledge among the car users the statements such as,

$>$ BMG:1The Brand has created a distinct image in my mind

BMG2:The Brand provides me relative life style

$>$ BMG3:The Brand is prestigious to me

BMG4:The Brand offers me luxury

BMG5:The Brand is flashy in its appearance

are examined on 5 point likert scale (Strongly Disagree to Strongly Agree) to develop the aggregate mean score and measure of standard deviation to identify which of the automobile brands have good Brand Image as per the perception of the car users.

The table 1.4.2 indicates that the mean scores and standard Deviations for the five automobile brands such as Maruti Suzuki, Tata motors, Mahindra \& Mahindra Hyundai and Toyota towards measuring Brand Image. The car users are of Maruti-Suzuki and Hyundai are of the opinion that they have developed good Brand Image (Aggregate Mean score 3.63), followed by Toyota (3.59) Mahindra \& Mahindra,(3.53), and the least score is 3.31 for Tata motors.

\begin{tabular}{|c|c|c|c|c|c|c|c|c|c|c|}
\hline $\mathrm{N}=200$ & \multicolumn{2}{|c|}{ Maruti-Suzuki } & \multicolumn{2}{|c|}{ Tata Motors } & \multicolumn{2}{|c|}{ MM } & \multicolumn{2}{|c|}{ Hyundai } & \multicolumn{2}{|c|}{ Toyota } \\
\hline 1.4.3 Brand Identity & Mean & SD & Mean & SD & Mean & SD & Mean & SD & Mean & SD \\
\hline $\begin{array}{l}\text { I feel elite when I see people using } \\
\text { cars of my Brand }\end{array}$ & 3.52 & 1.056 & 3.36 & 0.98 & 3.24 & 1.05 & 3.41 & 1.12 & 3.47 & 1.03 \\
\hline $\begin{array}{l}\text { The Brand helps me to } \\
\text { demonstrate social identity }\end{array}$ & 3.72 & 0.885 & 3.27 & 0.93 & 3.8 & 1.02 & 3.43 & 1.091 & 3.48 & 0.97 \\
\hline $\begin{array}{l}\text { The range of cars from the Brand } \\
\text { are compatible to the needs of the } \\
\text { consumers }\end{array}$ & 3.95 & 0.963 & 3.45 & 1.00 & 3.64 & 1.02 & 3.53 & 0.95 & 3.68 & 0.90 \\
\hline $\begin{array}{l}\text { The Brand gives me pleasure and } \\
\text { happiness }\end{array}$ & 3.69 & 1.099 & 3.63 & 0.90 & 3.83 & 0.93 & 3.72 & 1.075 & 3.85 & 0.80 \\
\hline Aggregate Mean \& SD & 3.72 & 1.0 & 3.42 & 0.95 & 3.62 & 1.005 & 3.52 & 1.06 & 3.62 & 0.93 \\
\hline
\end{tabular}

Brand Identity: Brand Identity refers to the visible elements of a brand (such as colours, design, logotype, name, symbol) that together identify and distinguish the brand in the consumers' mind. It is focused on the concept of how it has to perceived and recognized by its customers. SWOT analysis to analyze itself and its market is the rational yardstick to design and Build Brand Identity. (Ref: www.businessdictionary.com)

With the intention of quantifying Brand Identity among the car users the statements such as,

$>$ BI 1:I feel elite when I see people using cars of my Brand

$>$ BI 2:The Brand helps me to demonstrate social identity

$>$ BI 3:The range of cars from the Brand is compatible to the needs of the consumers

$>\mathrm{BI}$ 4:The Brand gives me pleasure and happiness

are examined on 5 point likert scale (Strongly Disagree to Strongly Agree) to develop the aggregate mean score and measures of standard deviation to identify which of the automobile brands have good Brand Identity as per the perception of the car users.

The table 1.4.3 indicates that the mean scores and standard Deviations for the five automobile brands such as Maruti Suzuki, Tata motors, Mahindra \& Mahindra Hyundai and Toyota towards measuring Brand Identity. The car users are of Maruti-Suzuki, Toyota motors and Hyundai are of the opinion that they have good Brand Identity (Aggregate Mean score 3.72, 3.62), followed by Hyundai (3.52) and Tata motors (3.42) the least score.

Brand Positioning: In simple terms brand positioning is the process of positioning a particular brand in the minds of target customers. Brand Positioning can be defined as an activity of creating a brand offer in such a 
manner that it occupies a distinctive place and value in the target customer's mind. Brand positioning refers to "target consumer's" reason to buy a particular brand in preference to others, more particularly brand positioning statements are for internal use, and not to be misunderstood either with symbols/logos/taglines. (Ref:www.businessdictionary.com)

\begin{tabular}{|c|c|c|c|c|c|c|c|c|c|c|}
\hline $\mathrm{N}=200$ & \multicolumn{2}{|c|}{ Maruti-Suzuki } & \multicolumn{2}{|c|}{ Tata Motors } & \multicolumn{2}{|c|}{ MM } & \multicolumn{2}{|c|}{ Hyundai } & \multicolumn{2}{|c|}{ Toyota } \\
\hline 1.4.4 Brand Positioning & Mean & SD & Mean & SD & Mean & SD & Mean & $\mathrm{SD}$ & Mean & SD \\
\hline I am familiar with the Brand & 3.96 & 1.10 & 3.44 & 1.15 & 3.25 & 1.01 & 3.98 & 0.84 & 3.62 & 0.91 \\
\hline The Brand satisfies my needs & 3.95 & 0.93 & 3.62 & 0.86 & 3.73 & 0.87 & 3.86 & 0.78 & 3.66 & 0.99 \\
\hline The Brand is environmental friendly & 3.81 & 0.97 & 3.29 & 0.92 & 3.77 & 0.84 & 3.65 & 0.92 & 3.60 & 0.99 \\
\hline $\begin{array}{l}\text { The Brand/company has clearly } \\
\text { Communicated its values through the } \\
\text { marketing channels }\end{array}$ & 3.73 & 0.92 & 3.35 & 0.90 & 3.46 & 0.74 & 3.76 & 0.81 & 3.61 & 0.81 \\
\hline $\begin{array}{l}\text { The Brand/company has established and } \\
\text { communicated the points of similarity with } \\
\text { respect to its competitors }\end{array}$ & 3.78 & 0.88 & 3.38 & 1.02 & 3.26 & 0.88 & 3.77 & 0.86 & 3.72 & 0.86 \\
\hline $\begin{array}{l}\text { The Brand/company has established and } \\
\text { communicated the points of difference } \\
\text { (disparity) with respect to its competitors }\end{array}$ & 3.60 & 0.97 & 3.35 & 0.97 & 3.48 & 0.97 & 3.66 & 0.92 & 3.59 & 0.88 \\
\hline $\begin{array}{l}\text { The Brand offers cars with unique safety } \\
\text { features }\end{array}$ & 3.82 & 1.01 & 3.37 & 1.01 & 3.77 & 0.97 & 3.82 & 0.93 & 3.76 & 0.85 \\
\hline Aggregate Mean \& SD & 3.80 & 0.96 & 3.4 & 0.97 & 3.53 & 0.89 & 3.78 & 0.86 & 3.65 & 0.89 \\
\hline
\end{tabular}

Source: Field survey

With the intention of quantifying Brand Identity among the car users the statements such as,

$>$ BPS 1:I am familiar with the Brand

$>$ BPS 2:The Brand satisfies my needs

$>$ BPS 3:The Brand is environmental friendly

$>$ BPS 4:The Brand/company has clearly Communicated its values through the marketing channels

$>$ BPS 5:The Brand/company has established and communicated the points of similarity with respect to its competitors

$>$ BPS 6:The Brand/company has established and communicated the points of difference (disparity) with respect to its competitors

$>$ BPS 7:The Brand offers cars with unique safety features

are examined on 5 point likert scale (Strongly Disagree to Strongly Agree) to develop the aggregate mean score and measures of standard deviation to identify which of the automobile brands have positioned well in the mind of the car users.

The table 1.4.4 indicates that the mean scores and standard Deviations for the five automobile brands such as Maruti Suzuki, Tata motors, Mahindra \& Mahindra Hyundai and Toyota towards measuring the strength of Brand positioning. The car users are of Maruti-Suzuki, Hyundai are of the opinion that the brands are positioned well in their minds (Aggregate Mean score 3.80, 3.78), followed by Toyota (3.65), Mahindra (3.53) and Tata motors (3.4) the least score.

\begin{tabular}{|c|c|c|c|c|c|c|c|c|c|c|}
\hline $\mathrm{N}=200$ & \multicolumn{2}{|c|}{ Maruti-Suzuki } & \multicolumn{2}{|c|}{ Tata Motors } & \multicolumn{2}{|c|}{$\mathrm{MM}$} & \multicolumn{2}{|c|}{ Hyundai } & \multicolumn{2}{|c|}{ Toyota } \\
\hline 1.4.5 Brand Trust & Mean & SD & Mean & SD & Mean & SD & Mean & SD & Mean & SD \\
\hline $\begin{array}{l}\text { I trust my Brand for its economical } \\
\text { maintenance }\end{array}$ & 3.75 & 1.1 & 3.56 & 0.73 & 3.16 & 1.07 & 3.61 & 0.93 & 3.71 & 1.00 \\
\hline I trust my Brand for its safety features & 3.70 & 0.93 & 3.48 & 0.92 & 3.85 & 0.93 & 3.67 & 0.89 & 3.89 & 0.76 \\
\hline $\begin{array}{l}\text { I trust my Brand for its performance } \\
\text { standards irrespective of the road } \\
\text { conditions }\end{array}$ & 3.71 & 1.0 & 3.59 & 0.80 & 3.69 & 0.93 & 3.72 & 0.94 & 3.86 & 0.78 \\
\hline $\begin{array}{l}\text { I trust my Brand for its long lasting } \\
\text { customer service }\end{array}$ & 3.99 & 0.93 & 3.75 & 0.78 & 3.68 & 0.83 & 3.74 & 0.98 & 3.85 & 0.76 \\
\hline $\begin{array}{l}\text { I Trust my Brand for its guaranteed } \\
\text { resale value }\end{array}$ & 3.88 & 1.06 & 3.35 & 1.09 & 3.64 & 0.98 & 3.53 & 0.97 & 3.94 & 0.81 \\
\hline Aggregate Mean \& SD & 3.81 & 1.00 & 3.54 & 0.86 & 3.60 & 0.95 & 3.65 & 0.94 & 3.85 & 0.82 \\
\hline
\end{tabular}

Source: Field survey

Brand Trust: The Brand Equity and its enhancement is considered to be a relational market based asset (Falkenberg, 1996; Hooley et al., 2005; Srivastava et al., 1998, 2001) because it exists even outside the firm (External environmental operatives) that is the in the minds of the final users of the brand's products. As far the existing branding literature is concerned the Brand Trust yet to receive its due representation for empirical evidences in building and enhancing Brand Equity (Chaudhuri and Holbrook 2001).But the importance of Brand trust was theoretically highlighted in the earlier branding literature(Ambler, 1997, Sheth and Parvatiyar, 1995,Bainbridge 1997, Kamp 1999,Scott 2000). Referring to the existing research brand trust 
(Andaleeb1992,Doney and Cannon1997; Larzelere and Huston, 1980),Brand Trust can be considered as the expectancy based on the consumer's belief that the brand has specific qualities that makes it more consistent, relevant, competent, honest, and promising, \&Responsible.(Elena Delgado-Ballester and Jose' Luis MunueraAlema'n 2005).Hence to trust a brand explicitly can be interpreted that there is a high probability or expectancy that the brand will result in positive outcomes/welcoming/pleasing benefits for the consumer, the first dimension of Brand Trust has a technical or competence based nature predominantly addressing the issues related to ability and willingness to keep promises and satisfy consumers' needs(Delgado et al. 2003 Doney\& Cannon 1997, Ganesan, 1994 Morgan and Hunt 1994).

With the intention of measuring Brand trust among the car users, the statements such as,

$>$ BT 1: I trust my Brand for its economical maintenance

$>$ BT 2: I trust my Brand for its safety features

$>$ BT 3: I trust my Brand for its performance standards irrespective of the road conditions

$>$ BT 4: I trust my Brand for its long lasting customer service

$>$ BT 5: I Trust my Brand for its guaranteed resale value

are examined on 5 point likert scale (Strongly Disagree to Strongly Agree) to develop the aggregate mean score and standard deviation to measure the brand trust among the car users of automobile brands under consideration.

The table 1.4.5 indicates that the mean scores and standard Deviations for the five automobile brands such as Maruti Suzuki, Tata motors, Mahindra \& Mahindra Hyundai and Toyota towards measuring the strength of Brand positioning. The car users of Toyota motors (3.85) are found to be of good Brand Trust followed by Maruti Suzuki (3.81), Hyundai (3.65), Mahindra \& Mahindra (3.60), and Tata motors (3.54) the least score.

\begin{tabular}{|c|c|c|c|c|c|c|c|c|c|c|}
\hline $\mathrm{N}=200$ & \multicolumn{2}{|c|}{ Maruti-Suzuki } & \multicolumn{2}{|c|}{ Tata Motors } & \multicolumn{2}{|c|}{ MM } & \multicolumn{2}{|c|}{ Hyundai } & \multicolumn{2}{|c|}{ Toyota } \\
\hline 1.4.6 Brand Loyalty & Mean & SD & Mean & SD & Mean & SD & Mean & SD & Mean & $\mathrm{SD}$ \\
\hline I consider I am loyal to the Brand & 3.47 & 1.16 & 3.39 & 1.11 & 3.31 & 1.10 & 3.51 & 0.92 & 3.46 & 1.02 \\
\hline I feel I made a right choice & 3.76 & 1.061 & 3.75 & 0.87 & 3.79 & 0.99 & 3.70 & 1.01 & 3.54 & 1.07 \\
\hline $\begin{array}{l}\text { I would continue with preference to } \\
\text { buy cars from the same Brand } \\
\text { irrespective of increase in price }\end{array}$ & 3.44 & 1.15 & 3.35 & 1.08 & 3.51 & 1.02 & 3.37 & 0.93 & 3.45 & 1.06 \\
\hline $\begin{array}{l}\text { Next car that I buy would be from the } \\
\text { same Brand }\end{array}$ & 3.43 & 1.01 & 3.24 & 0.98 & 3.39 & 1.026 & 3.32 & 1.08 & 3.50 & 1.08 \\
\hline $\begin{array}{l}\text { I prefer to buy the car of my Brand } \\
\text { even at the higher prices }\end{array}$ & 3.44 & 1.06 & 3.18 & 1.03 & 3.48 & 0.94 & 3.31 & 0.99 & 3.49 & 1.05 \\
\hline $\begin{array}{l}\text { I am satisfied with the cars of all } \\
\text { colours and segments of the Brand }\end{array}$ & 3.61 & 1.15 & 3.48 & 1.03 & 3.67 & 1.06 & 3.54 & 1.01 & 3.54 & 1.23 \\
\hline
\end{tabular}

Source: Field survey

Brand Loyalty: It is one of the major determinants of Brand Resonance. Brand Resonance describes the nature of Brand Consumer relationship and the extent to which the consumer's feelings, emotions and attitudes are in synchronization with the Brand. It reflects the depth of psychological bonding that the consumers enjoy pleasurably. The Brand Resonance/very strong brand attachment can be divided into four categories.

$>$ Behavioral Loyalty

$>$ Attitudinal Attachment

$>$ Sense of Community

$>$ Active Engagement

Behavioral Loyalty refers to the repeated purchases and the volume of purchase, in general it refers to how much the consumers purchase and how often they purchase a particular brand's products/services. Behavioral loyalty may result in highly persistent word of mouth advertisements, references to friends, relatives, and will help to build relationship capital for the company (Keller 2011)

With the intention of measuring Brand Loyalty among the car users, the statements such as,

BL1:I consider I am loyal to the Brand

$>$ BL 2:I feel I made a right choice

$>$ BL3:I would love to recommend the Brand to my friends

$>$ BL 4:I would continue with preference to buy cars from the same Brand irrespective of increase in price

$>$ BL 5:Next car that I buy would be from the same Brand

BL 6:I prefer to buy the car of my Brand even at the higher prices

$>$ BL 7:I am satisfied with the cars of all colours and segments of the Brand

are examined on 5 point likert scale (Strongly Disagree to Strongly Agree) to develop the aggregate mean score and standard deviation to measure Brand Loyalty among the car users of automobile brands under consideration. 
The table 1.4.6 indicates that the mean scores and standard Deviations for the five automobile brands such as Maruti Suzuki, Tata motors, Mahindra \& Mahindra Hyundai and Toyota towards measuring the strength of Brand Loyalty. The car users of Mahindra and Mahindra are found to be more loyal (3.57) followed by MarutiSuzuki (3.55), Toyota (3.54),Hyundai (3.5) and Tata motors (3.41) with least score

\begin{tabular}{|c|c|c|c|c|c|c|c|c|c|c|}
\hline $\mathrm{N}=200$ & \multicolumn{2}{|c|}{ Maruti-Suzuki } & \multicolumn{2}{|c|}{ Tata Motors } & \multicolumn{2}{|c|}{$\mathrm{MM}$} & \multicolumn{2}{|c|}{ Hyundai } & \multicolumn{2}{|c|}{ Toyota } \\
\hline 1.4.7Brand Associations & Mean & SD & Mean & SD & Mean & SD & Mean & SD & Mean & SD \\
\hline $\begin{array}{l}\text { I admire the people who use the cars of } \\
\text { my Brand }\end{array}$ & 3.54 & 1.16 & 3.37 & 1.09 & 3.46 & 1.04 & 3.57 & 1.04 & 3.59 & 0.98 \\
\hline $\begin{array}{l}\text { I have favorable and positive associations } \\
\text { in my mind towards the Brand }\end{array}$ & 3.64 & 0.91 & 3.46 & 0.98 & 3.56 & 0.97 & 3.68 & 0.86 & 3.88 & 0.77 \\
\hline $\begin{array}{l}\text { My Brand is associated with creativity } \\
\text { and Innovation }\end{array}$ & 3.6 & 1.01 & 3.52 & 0.94 & 3.51 & 1.02 & 3.72 & 0.93 & 3.86 & 0.87 \\
\hline $\begin{array}{l}\text { My Brand is associated with advanced } \\
\text { technology }\end{array}$ & 3.58 & 0.97 & 3.67 & 0.90 & 3.64 & 0.87 & 3.80 & 0.92 & 3.95 & 0.77 \\
\hline $\begin{array}{l}\text { My Brand is associated with fuel } \\
\text { economy/mileage efficiency }\end{array}$ & 3.81 & 0.92 & 3.85 & 0.86 & 3.66 & 0.89 & 3.71 & 0.89 & 3.86 & 0.79 \\
\hline $\begin{array}{l}\text { My Brand offers best selling cars in all } \\
\text { segments }\end{array}$ & 3.78 & 1.1 & 3.68 & 0.77 & 3.57 & 0.85 & 3.82 & .91 & 4.03 & 0.69 \\
\hline $\begin{array}{l}\text { My Brand is known for its safety and } \\
\text { comfort }\end{array}$ & 3.74 & 1.0 & 3.63 & 0.84 & 3.76 & 0.90 & 3.77 & 0.74 & 3.83 & 0.90 \\
\hline $\begin{array}{l}\text { My Brand is known for its after sales } \\
\text { service support }\end{array}$ & 3.89 & 0.91 & 3.63 & 0.70 & 3.63 & 0.85 & 3.73 & 0.79 & 3.81 & 0.97 \\
\hline $\begin{array}{l}\text { My Brand is the attention setter among } \\
\text { the crowd of its competitors. }\end{array}$ & 3.59 & 1.08 & 3.28 & 1.10 & 3.67 & 0.92 & 3.68 & 0.91 & 3.85 & 0.90 \\
\hline It is my Family car & 4.0 & 0.98 & 3.88 & 0.79 & 3.79 & 0.91 & 3.89 & 0.92 & 4.06 & 0.93 \\
\hline Aggregate Mean \& SD & 3.71 & 1.00 & 3.59 & 0.89 & 3.62 & 0.92 & 3.73 & 0.89 & 3.87 & 0.85 \\
\hline
\end{tabular}

Source: Field survey

Brand Associations: The Brand Associations are related to the thought patterns of the consumers regarding the retrieval of product/brand information and relates it to the existing brand knowledge. Determinants of strength of the associations are the brand Consistency and its relevance to both functional and emotional benefits. The brand attributes, salient features and the consumer's direct/indirect attachments/experiences also determine the strength of Brand associations, and higher the strength of the associations higher will be the effect of brand resonance (Keller 2011)

With the intention of measuring Brand Loyalty among the car users, the statements such as,

$>$ BAS 1:I admire the people who use the cars of my Brand

$>$ BAS 2:I have favourable and positive associations in my mind towards the Brand

$>$ BAS 3:My Brand is associated with creativity and Innovation

$>$ BAS 4:My Brand is associated with advanced technology

$>$ BAS 5:My Brand is associated with fuel economy/mileage efficiency

$>$ BAS 6:My Brand offers best selling cars in all segments

BAS 7:My Brand is known for its safety and comfort

$>$ BAS 8:My Brand is known for its after sales service support

$>$ BAS 9: My Brand is the attention setter among the crowd of its competitors.

$>$ BAS 10:It is my Family car

are examined on 5 point likert scale (Strongly Disagree to Strongly Agree) to develop the aggregate mean score and standard deviation to measure Brand Associations among the car users of automobile brands under consideration.

The table 1.4.7 indicates that the mean scores and standard Deviations for the five automobile brands such as Maruti Suzuki, Tata motors, Mahindra \& Mahindra Hyundai and Toyota towards measuring the strength of Brand Associations. The car users of Toyota brand are found to have developed highly favorable associations (3.87), followed by Hyundai (3.73),Maruti Suzuki (3.71),Mahindra \& Mahindra (3.62) and Tata Motors with mean score (3.59).

\begin{tabular}{|c|c|c|c|c|c|c|c|c|c|c|}
\hline $\mathrm{N}=200$ & \multicolumn{2}{|c|}{ Maruti-Suzuki } & \multicolumn{2}{|c|}{ Tata Motors } & \multicolumn{2}{|c|}{ MM } & \multicolumn{2}{|c|}{ Hyundai } & \multicolumn{2}{|c|}{ Toyota } \\
\hline 1.4.8 Perceived quality & Mean & SD & Mean & SD & Mean & SD & Mean & SD & Mean & SD \\
\hline $\begin{array}{l}\text { The engine performance \& the } \\
\text { mileage of my Brand gives me high } \\
\text { satisfaction }\end{array}$ & 3.61 & 1.07 & 3.52 & 1.14 & 3.54 & 1.12 & 3.85 & 0.98 & 3.77 & 0.88 \\
\hline $\begin{array}{l}\text { Cars from my Brand offers excellent } \\
\text { features }\end{array}$ & 3.68 & 0.95 & 3.32 & 0.99 & 3.53 & 1.016 & 3.66 & 0.97 & 3.82 & 0.81 \\
\hline My social status is high due to the car & 3.33 & 1.13 & 3.35 & 0.98 & 3.38 & 0.97 & 3.57 & 1.06 & 3.74 & 0.84 \\
\hline $\begin{array}{l}\text { I am Highly satisfied with the quality } \\
\text { of the Brand }\end{array}$ & 3.84 & 0.87 & 3.63 & 0.83 & 3.63 & 0.93 & 3.74 & .98 & 3.89 & 0.84 \\
\hline $\begin{array}{l}\text { My next car would be from the same } \\
\text { Brand }\end{array}$ & 3.34 & 1.08 & 3.29 & 0.97 & 3.52 & 0.96 & 3.33 & 1.02 & 3.64 & 0.91 \\
\hline
\end{tabular}


Building Brands A Study With Special Reference To Small Car Market In India

\begin{tabular}{|l|l|l|l|l|l|l|l|l|l|l|}
\hline $\begin{array}{l}\text { Performance and Reliability of the } \\
\text { Brand is better than its competitors }\end{array}$ & 3.57 & 0.93 & 3.45 & 0.93 & 3.68 & 1.03 & 3.57 & 1.03 & 3.82 & 0.88 \\
\hline Aggregate Mean \& SD & 3.56 & 1.00 & 3.43 & 0.97 & 3.54 & 1.00 & $\mathbf{3 . 6 2}$ & 1.00 & $\mathbf{3 . 7 8}$ & 0.86 \\
\hline
\end{tabular}

Source: Field survey

Perceived quality: It is the perception of the customers regarding the overall quality/Performance against the set standards and functional superiority with respect to the intended purpose. Achieving one time excellence in perceived quality may not be sufficient for building strong brands because over the years of performance the customers' expectations will be heightened leads to increased expectations in terms technical up gradations and high performance standards. Perceived quality seems to be relatively dynamic as the technical obscelence and updates will be cyclical in nature.

With the intention of measuring Perceived Quality among the car users, the statements such as,

$>\mathrm{PQ}$ 1:The engine performance \& the mileage of my Brand gives me high satisfaction

$>\mathrm{PQ}$ 2:Cars from my Brand offers excellent features

$>\mathrm{PQ}$ 3:My social status is high due to the car

$>$ PQ 4:I am Highly satisfied with the quality of the Brand

PQ 5:My next car would be from the same Brand

$>$ PQ 6:Performance and Reliability of the Brand is better than its competitors

are examined on 5 point likert scale (Strongly Disagree to Strongly Agree) to develop the aggregate mean score and standard deviation to measure Perceived Quality among the car users of automobile brands under consideration.

The table 1.4.8 indicates that the mean scores and standard Deviations for the five automobile brands such as Maruti Suzuki, Tata motors, Mahindra \& Mahindra Hyundai and Toyota towards measuring the strength of Perceived quality. The car users of Toyota brand are found to have developed high Perceived Quality (3.78), followed by Hyundai (3.62),Maruti Suzuki (3.56),Mahindra \& Mahindra (3.54) and Tata Motors with mean score (3.43).

\begin{tabular}{|l|l|l|l|l|l|l|l|l|}
\hline \multirow{2}{*}{ Car Brands } & \multicolumn{9}{|l|}{ Aggregate Mean Scores } \\
\cline { 2 - 10 } & BK & BMG & BI & BPS & BT & BL & BAS & PQ \\
\hline Maruti Suzuki & 3.87 & 3.63 & 3.72 & 3.8 & 3.81 & 3.55 & 3.71 & 3.56 \\
\hline Tata Motors & 3.46 & 3.31 & 3.42 & 3.4 & 3.54 & 3.41 & 3.59 & 3.43 \\
\hline Mahindra and Mahindra & 3.757 & 3.53 & 3.62 & 3.53 & 3.6 & 3.57 & 3.62 & 3.54 \\
\hline Hyundai & 3.87 & 3.63 & 3.52 & 3.78 & 3.65 & 3.5 & 3.73 & 3.62 \\
\hline Toyota & 3.76 & 3.59 & 3.62 & 3.65 & 3.85 & 3.54 & 3.87 & 3.78 \\
\hline
\end{tabular}

Source: Field survey

\section{Aggregate Mean Scores}

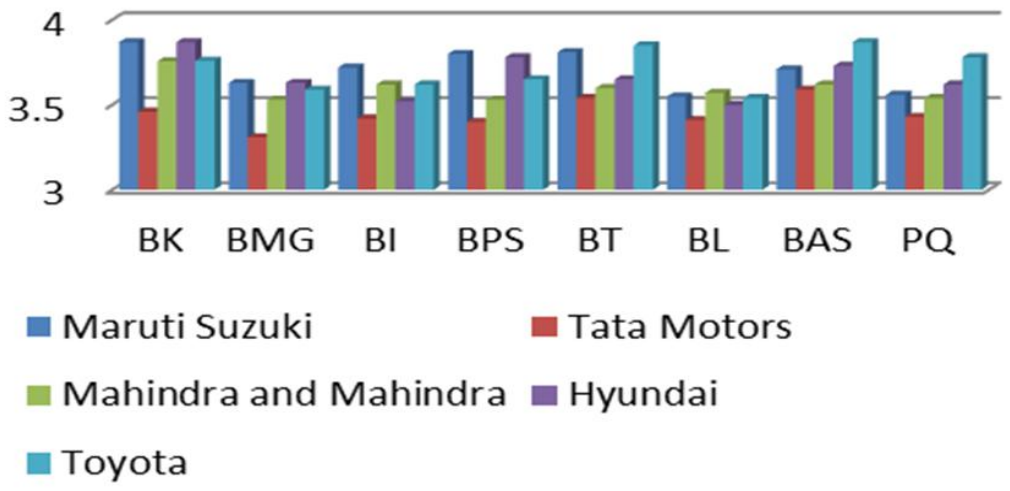

Source: Field survey

\begin{tabular}{|l|l|}
\hline Car Brands & Brand Strength \\
\hline Maruti Suzuki & 3.71 \\
\hline Tata Motors & 3.5 \\
\hline Mahindra and Mahindra & 3.6 \\
\hline Hyundai & 3.7 \\
\hline Toyota & 3.71 \\
\hline
\end{tabular}


In aggregate Maruti -Suzuki, Hyundai and Toyota brands are found to be Strong brands, Mahindra Mahindra and Mahindra still to emerge as a strong brand Tata motors Brand Strength is comparatively less.It is also major finding to quote that Maruti Suzuki,Toyota motors and Hyundai are the strong competitors for their market share followed by Mahindram \& Mahindra and Tata motors in the Indian Small car Market.

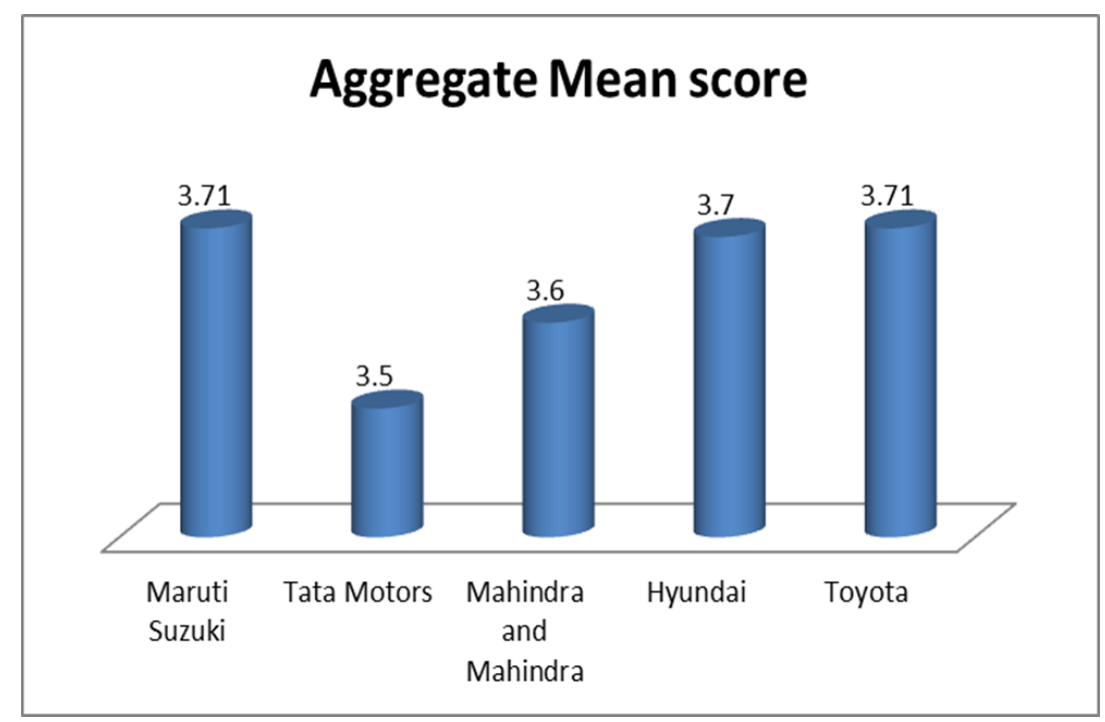

\section{Conclusions}

The objective and the research statement are thoroughly examined to identify the key Brand Building Dimensions. The mean score and the standard deviation measures provide substantial empirical evidences to explore the competitive market conditions in support of the fact that Red oceans have made the Indian Automobile industry more competitive and no much innovation are reported. The game of acquiring new market share is predominantly ruled by the concept of Zero sum game.

Therefore it is the right time to recommend that the Indian Automobile manufacturers should focus their R\&D efforts in creating the Blue oceans among the existing red oceans to create un contested market space and to introduce the products with human computer interface, Smart cars, and Hybrid fuel technologies. Probably the next generation automobiles may be fitted with engines driven by solar/ Lithium Batteries/Hydrogen gas, and the R\&D efforts said be happening at Tesla and Google, may turn out to be highly iconic for the generations to come.

\section{References}

\section{Websites:}

[1]. www.siam.com

[2]. www.businessdictionary.com

[3]. www.kpmg.com

[4]. http://www.ibef.org/industry/india- automobiles.aspx\#sthash.yZxctbO1.dpuf

[5]. KPMG Report on Auto Industry in the changing world order

[6]. www.ancient-origins.net/ancient.../revolutionary-invention-wheel-00171.

[7]. www.notap.gov.ng/content/history-invention-wheel

[8]. shodhganga.inflibnet.ac.in/bitstream/.../2/02.\%20complete\%20thesis.pdf

\section{Published reports:}

[9]. Media Reports,

[10]. Press Releases -Business Standard ,Economic Times (2014-15,2015-16)

[11]. Department of Industrial Policy and Promotion (DIPP)

[12]. Automotive Component Manufacturers Association of India (ACMA),

[13]. Society of Indian Automobile Manufacturers (SIAM),

[14]. Union Budget 2015-16, Union Budget 2016-17.

[15]. Automotive Mission Plan 2006-2016

[16]. National Electric Mobility and Mission Plan (NEMMP 2020)

\section{Research Articles:}

[17]. Kapferer, J.N. and Laurent, G. 1985, "Brand sensitivity: a new concept for brand management", Proceedings of the Annual Conference ot the European Marketing Academy.

[18]. Aaker, D.A. 1991, Managing Brand Equity: Capitalizing onthe Value of a Brand Name, Free Press, New York, NY.

[19]. Andaleeb, S.S. (1992), “The trust concept: research issues forchannels of distribution”, Research in Marketing, Vol. 11, pp. 1-34.

[20]. Keller, K.L. 1993, "Conceptualizing, measuring, and managing customer-based brand equity", Journal of Marketing, Vol. 57, January, pp. 1-22. 
[21]. Kapferer, J.N. and Laurent, G. (1993), "Further Evidence on the Consumer Involvement Profile: Five Antecedents of Involvement", Psychology and Marketing, 10 (4), 347-357.

[22]. Falkenberg, A.W. 1996, "Marketing and the wealth offirms", Journal of Macromarketing, Vol. 16 No. 1, pp. 4-24.

[23]. Ambler, Tim 1997, "How much brand equity is explained by trust?", Management Decision, 35 (4), $283-292$.

[24]. Fournier, S. 1998, "Consumers and their brands: deviations from the Dirichlet model for repeat purchasing", Journal of Marketing Research, 30 (November), 478-93.

[25]. Yoo, B. and Donthu, N. (2001), "Developing and validating a multi-dimensional consumer-based brand equity scale", Journal of Business Research, Vol. 52 No. 1, pp. 1-14.

[26]. Chaudhuri A. Holbrook M.B 2001. The chain of effects from brand trust and brand affect to brand Performance: The role of brand loyalty. Journal of Marketing 65 (April): 81-93.

[27]. Delgado et.al, 2005 does brand trust matter to brand equity? Journal of Product and Brand Management 187-196

Text Book:

[28]. W.Chan Kim et. al 2005 Blue Ocean Strategy: Making Competition Irrelevant 